\title{
Analisis Kandungan Total Coliform pada Air Galon dan Higiene Sanitasi Perorangan Operator Depot Air Minum Isi Ulang (Studi Kasus: Kecamatan Koto Tangah, Kota Padang)
}

\author{
Nadya Khairannisa Andrizal ${ }^{1 *}$, Rinda Andhita Regia ${ }^{1 * *}$, Shinta Silvia $^{1}$ \\ ${ }^{1}$ Program Studi Teknik Lingkungan Universitas Andalas \\ *e-mail:nadya.andrizal@gmail.com; **shintasilvia2476@gmail.com
}

\begin{abstract}
This study aims to analyze Total Coliform and its correlations with DAMIU sanitation hygiene in Koto Tangah District, Padang City. The study was conducted by sampling and questionnaires. Samples were obtained from 10 DAMIU consisting of raw water in the reservoir and the production water then carried out in duplicate. Interviews were conducted using questionnaires to DAMIU operators and observations to observe the sanitation of DAMIU. The analytical method used to determine the amount of Total Coliform is the MPN method. The type of question in the questionnaire is the close ended question with the Guttman scale. The results showed that Total Coliform in raw water ranged from 12-64 MPN / $100 \mathrm{ml}$ and production water ranged from 6.2-15 MPN / $100 \mathrm{ml}$ that it did not meet the quality standard limit based on Permenkes 492/2010, which was 0 MPN / $100 \mathrm{ml}$. After the complementary test, it is known that $50 \%$ of raw water samples and $20 \%$ of processed water are positive for E. coli bacteria. The results of the questionnaire showed that the personal hygiene on the DAMIU operators were $6.6 \%$ at "less" attitude of, $66.7 \%$ at "sufficient" and $26.7 \%$ at "good". The relationship between sanitation hygiene and Total Coliform in AMIU is inversely proportional and has a very strong correlation with the $r$ value of 0.770 in raw water equipment hygiene, then 0.751 in equipment and production sites hygiene, and 0.831 in personal hygiene of the operator. The personal hygiene of the operator is the most influential aspect among the three aspects seen from the greatest $r$ value.
\end{abstract}

Keywords : DAMIU; Sanitation hygiene; Koto Tangah District Padang City; Total Coliform

\section{Pendahuluan}

Meningkatnya kebutuhan air bersih sebagai sumber air minum bagi masyarakat menjadi alasan berkembangnya industri-industri penyediaan air minum dalam kemasan (AMDK). Harga AMDK dari berbagai merek yang relatif mahal menyebabkan AMDK sebagian besar hanya dikonsumsi oleh masyarakat dengan tingkat ekonomi menengah ke atas. Masyarakat kemudian mencari cara lain untuk mendapatkan air yang layak minum, yaitu dengan air minum isi ulang (AMIU) yang berasal dari depot air minum dengan harga yang relatif lebih terjangkau (Bambang, 2014).

Berdasarkan data dari Dinas Kesehatan Kota Padang terjadi pertumbuhan depot air minum isi ulang (DAMIU) secara signifikan. Tercatat pada tahun 2013 terdapat 563 DAMIU, tahun 2015 sebanyak 612 DAMIU dan pada tahun 2017 sebanyak 867 DAMIU. DAMIU terbanyak di Kota Padang terdapat di Kecamatan Koto Tangah dengan jumlah DAMIU sebanyak 164 DAMIU.

Pertumbuhan DAMIU di Kota Padang yang signifikan ini tidak menjamin terlaksananya higiene sanitasi depot air minum yang memenuhi persyaratan. Penelitian yang dilakukan oleh Wandrivel (2012) tentang kualitas air minum pada DAMIU di Kecamatan Bungus Padang menunjukkan $55,5 \%$ sampel tidak memenuhi persyaratan secara mikrobiologis. Beberapa faktor yang dapat mempengaruhi kualitas AMIU yang dihasilkan yaitu sumber air baku, kondisi DAMIU, kebersihan operator dan penanganan terhadap wadah konsumen.

Total Coliform dalam air dapat disebabkan oleh desinfeksi yang tidak sempurna. Proses desinfeksi ini terdapat pada pencucian dan pembilasan galon yang rawan pencemaran apabila tidak dilakukan dengan benar. Faktor lain yang dapat mempengaruhi kualitas air hasil produksi adalah air baku, jenis peralatan yang digunakan, pemeliharaan peralatan dan penanganan pengolahan dan pendistribusian air. Hal ini sesuai dengan hasil penelitian yang dilakukan oleh Athena (2004) tentang kandungan bakteri Total Coliform dan E. coli air minum dari DAMIU di Kota Jakarta, Tangerang, dan Bekasi. Selain faktor-faktor di atas, pertumbuhan bakteri Total Coliform sangat dipengaruhi oleh keadaan lingkungan seperti kondisi fisik yaitu suhu dan pH. (Rofi'I, 2009).

Berdasarkan data dari puskesmas yang terletak di Kecamatan Koto Tangah yaitu puskesmas Lubuk Buaya, Dadok Tunggul Hitam, Anak Air, KPIK dan Air Dingin menunjukkan bahwa pada tahun 2016 diare menjadi penyakit menular tertinggi dengan jumlah kasus yang tercatat sebanyak 2.863 kasus. Salah satu penyebabnya adalah kesehatan lingkungan yang buruk dan perilaku hidup bersih dan sehat (PHBS) masyarakat terutama pada DAMIU yang menjadi tanggung jawab operator. PHBS operator yang masih rendah disebabkan kurangnya pengawasan terhadap usaha DAMIU (Dinas Kesehatan Kota Padang, 2016). Menurut Kepmenperindag RI No 651/MPP /Kep/10/2004 tentang Persyaratan Teknis Depot Air Minum dan Perdagangannya, pengawasan dan pemantauan terhadap DAMIU dilakukan pada seluruh aspek meliputi air baku, peralatan produksi, higiene perorangan operator/karyawan dan fasilitas sanitasi DAMIU.

\section{Metodologi}

Penelitian ini dilakukan untuk menganalisis kandungan Total Coliform yang dikaitkan dengan higiene sanitasi perorangan operator DAMIU di Kecamatan Koto Tangah Kota Padang. Dalam penelitian ini diamati dan dianalisis faktor-faktor yang mempengaruhi kandungan Total Coliform , yang ditinjau dari sanitasi DAMIU, air baku yang terdapat dalam tandon dan air hasil produksi berupa Air Minum Isi Ulang (AMIU) yang akan dijual ke konsumen. 
Penelitian dilakuan dengan pengambilan sampel dan kuesioner. Sampel didapatkan dari 10 DAMIU yang terdiri dari air baku di dalam tandon dan air hasil produksi kemudian dilakukan secara duplo. Selanjutnya dilakukan wawancara menggunakan kuesioner kepada operator dan observasi untuk mengamati keadaan sanitasi DAMIU.

Pengambilan sampel dilakukan dengan teknik random sampling. DAMIU yang digunakan sebagai tempat penelitian yaitu sebanyak 10 DAMIU yang berada di Kecamatan Koto Tangah dengan kapasitas produksi yang tinggi per harinya, menggunakan air baku yang berasal dari sumber mata air Gunung Talang dan menggunakan sistem ultraviolet pada proses disinfeksi air. Jumlah sampel yang diambil dalam satu DAMIU yaitu sebanyak dua sampel yang terdiri dari air baku yang terdapat dalam tandon DAMIU dan air hasil produksi DAMIU.

Data kandungan Total Coliform yang terdapat dalam sampel yaitu air baku dalam tandon dan air hasil produksi dianalisis laboratorium dengan metode MPN mengacu pada Food and Drug Association (FDA). Data higiene sanitasi perorangan didapatkan melalui kuesioner yang dibagikan kepada operator DAMIU. Kuesioner yang dibagikan kepada operator dijadikan sebagai data primer dalam penelitian. Penilaian kuesioner menggunakan skala Guttman dimana setiap jawaban "YA" bernilai 1 dan setiap jawaban "TIDAK" bernilai 0 .

\section{Hasil dan Pembahasan}

\subsection{Kandungan Total Coliform pada DAMIU}

Hasil pengujian sampel DAMIU dapat dilihat pada pada Gambar 1.

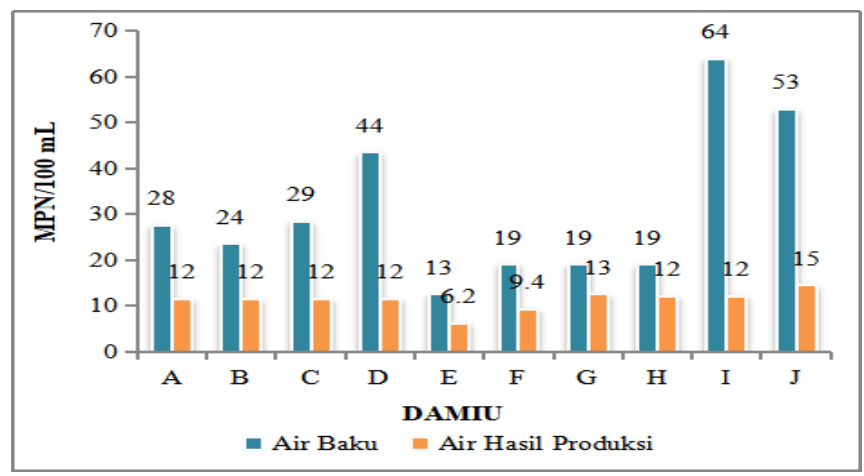

Gambar 1. Hasil pengukuran parameter total coliform pada DAMIU

Berdasarkan Gambar 1 pada hasil pengukuran air baku di dalam tandon menunjukkan bahwa seluruh sampel DAMIU tidak memenuhi standar baku mutu yang telah ditetapkan oleh PERMENKES 492/MENKES/PER/IV/2010. Kandungan Total Coliform tertinggi pada air baku terdapat pada DAMIU I dengan jumlah Total Coliform sebanyak 64 MPN/100 ml. Sedangkan kandungan Total Coliform pada air baku yang paling sedikit yaitu pada DAMIU E dengan jumlah 13 MPN/100 ml. Seluruh sampel DAMIU mengambil air baku yang berasal dari mata air Gunung Talang. Adanya Total Coliform pada air baku ini menjadi acuan untuk dilakukan pengkajian dan tinjauan ulang terhadap mata air yang dijadikan air baku untuk DAMIU apakah layak atau tidak.
Keberadaan kandungan Total Coliform pada air baku kemungkinan dapat disebabkan oleh keadaan mata air di sumber yang mungkin sudah tercemar maupun pada proses pengambilan air baku yang kurang diperhatikan kebersihannya. Air baku yang diangkut menggunakan mobil tangki akan memungkinkan terjadinya pencemaran selama dalam perjalanan dan menyebabkan mikroorganisme berkembang. Hal yang sama juga dikemukakan oleh Athena (2004) dan Rahayu (2013) bahwa sampel air baku yang tidak memenuhi persyaratan kemungkinan besar disebabkan oleh sumber mata air baku yang tercemar atau tercemarnya air baku pada saat pengangkutan dari sumber air ke lokasi DAMIU. Keadaan tandon air baku yang kotor dan tidak higienis juga memungkinkan terjadinya perkembangbiakan mikroorganisme. Hal ini bisa disebabkan karena kurangnya perhatian operator dalam menjaga kebersihan tandon dan tidak dilakukannya pembersihan secara berkala.

Air hasil produksi semuanya menunjukkan hasil positif adanya Total Coliform . Kandungan Total Coliform pada air hasil produksi menunjukkan adanya penurunan jika dibandingkan dengan kandungan Total Coliform pada air baku. Kandungan Total Coliform tertinggi pada air hasil produksi terdapat pada DAMIU J dengan jumlah Total Coliform sebanyak 15 MPN/100 ml. Sedangkan kandungan Total Coliform pada air hasil produksi yang paling sedikit yaitu pada DAMIU E dengan jumlah 6,2 MPN/100 ml. Menurut Tirta (2017) menurunnya kandungan Total Coliform pada air produksi disebabkan oleh beberapa tahap penyaringan atau filtrasi dan diakhiri dengan proses desinfeksi. Filtrasi bertujuan untuk memisahkan kontaminan tersuspensi dan berbentuk koloid serta memisahkan mikroorganisme dari dalam air, sedangkan desinfeksi bertujuan untuk membunuh mikroorganisme.

Kandungan Total Coliform yang masih ada pada air hasil produksi disebabkan karena proses disinfeksi yang kurang sempurna. Proses pengolahan (filtrasi dan desinfeksi) yang tidak sempurna dapat menyebabkan berkembangnya bakteri di dalam air minum. Selain itu faktor lain yang dapat mempengaruhi kualitas air hasil produksi adalah air baku, jenis peralatan yang digunakan, pemeliharaan peralatan dan penanganan air. Berdasarkan hasil observasi juga ditemukan 5 DAMIU yang menggunakan peralatan produksi yang sudah tidak layak pakai. Artinya, kurangnya perawatan peralatan produksi secara berkala dapat menyebabkan air menjadi tercemar. Hal yang sama dikemukakan oleh Marpaung (2013) yang menyatakan bahwa pemeliharaan peralatan air minum yang tidak optimal juga menjadi penyebab kontaminasi bakteri. Apabila sarana pengolahan air minum kurang baik dapat memungkinkan adanya kontaminasi mikroba patogen pada air minum (Radji, 2008).

\subsection{Higiene Sanitasi DAMIU}

Proses pengolahan air pada DAMIU tidak seluruhnya dilakukan secara otomatis. Terdapat beberapa proses yang harus dikerjakan secara langsung oleh operator. Operator/pekerja merupakan individu yang menangani proses yang terjadi pada DAMIU. Salah satu langkahnya yaitu pembersihan galon dan proses pengisian air ke dalam galon. Athena (2014) menyebutkan bahwa galon akan mengalami kontak langsung dengan operator. Hal ini menyebabkan sikap dan perilaku operator juga ikut serta 
berpengaruh terhadap kualitas air minum yang dihasilkan. Oleh karena itu kondisi higiene sanitasi operator DAMIU juga perlu diperhatikan. Selain itu peralatan air baku, serta peralatan dan kondisi tempat produksi juga memberikan kontribusi terhadap kualitas air minum yang dihasilkan.

\section{A. Higiene Sanitasi Peralatan Air Baku}

Hasil dari pencapaian operator DAMIU terhadap higiene peralatan air baku dapat dilihat pada Gambar 2 berikut.

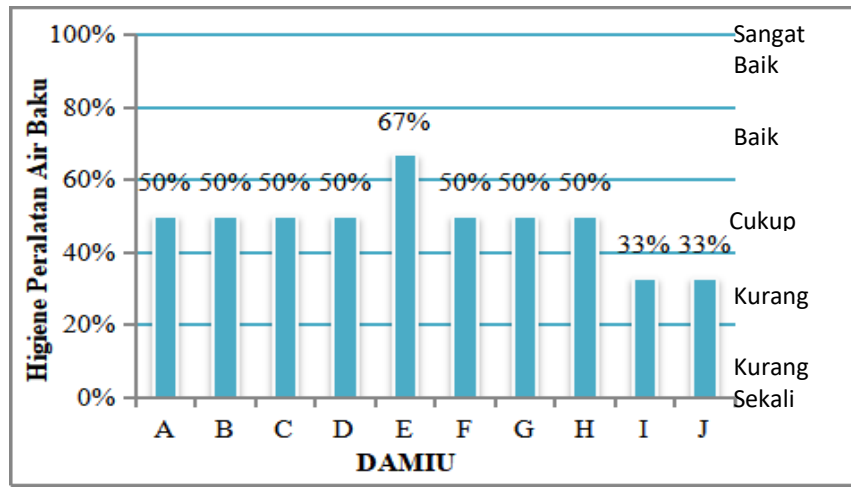

Gambar 2. Persentase sikap karyawan DAMIU terhadap peralatan air baku

Seluruh DAMIU tidak memiliki bukti tertulis sertifikat sumber air. Selain itu pihak DAMIU tidak mengetahui adanya bukti tertulis tentang kualitas air baku meliputi persyaratan fisik, mikrobiologi dan kimia sesuai persyaratan kualitas air minum. DAMIU E merupakan satu satunya DAMIU yang melakukan pembersihan tandon secara berkala sedangkan 9 DAMIU yang lainnya tidak pernah melakukan permbersihan tandon sejak tandon digunakan untuk pertama kalinya.

\section{B. Higiene Sanitasi Peralatan dan Tempat Produksi}

Hasil dari pencapaian operator DAMIU terhadap higiene peralatan air baku dapat dilihat pada Gambar 3 berikut.

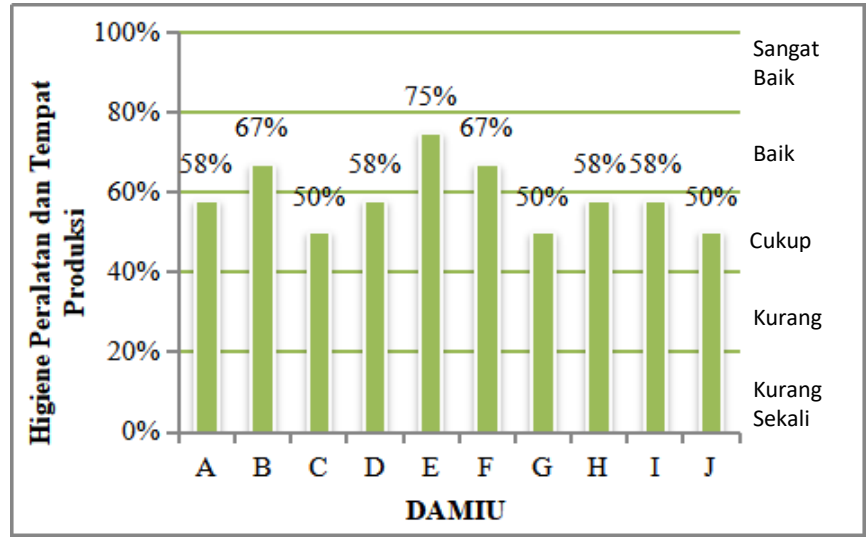

Gambar 3. Persentase sikap karyawan DAMIU terhadap peralatan dan kondisi tempat produksi

Terdapat 3 DAMIU yang bersikap baik dalam penanganan peralatan produksi dan kondisi tempat produksi. Dapat dilihat bahwa nilai pencapaian presentase seluruh DAMIU berada pada rentang 50-75\%. Seluruh sampel operator DAMIU yang berada di Kecamatan Koto Tangah berada pada kategori cukup dan baik terhadap penanganan peralatan produksi dan kondisi tempat produksi.

\section{Higiene Sanitasi Operator}

Hasil dari pencapaian higene sanitasi operator DAMIU dapat dilihat pada Gambar 4.

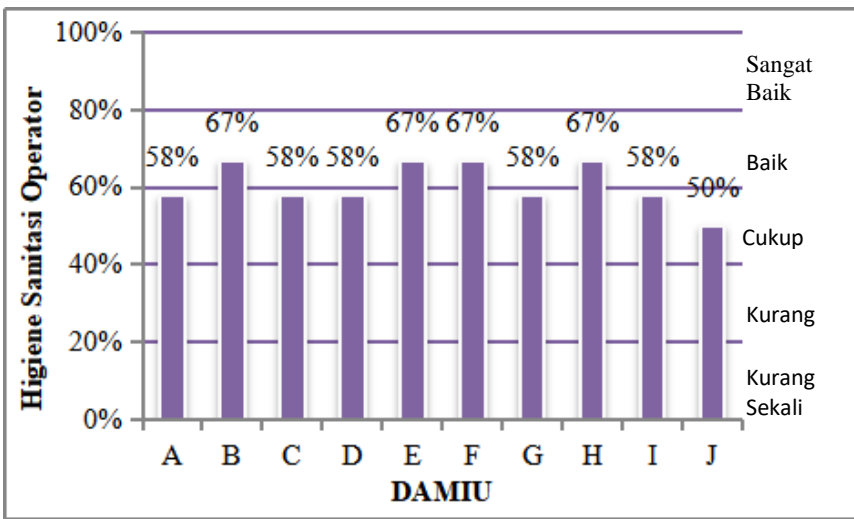

Gambar 4. Persentase sikap karyawan DAMIU terhadap higiene sanitasi operator

Dari Gambar 4 terdapat 4 DAMIU yang bersikap baik terhadap higiene sanitasi operator. Dapat dilihat bahwa nilai pencapaian presentase seluruh DAMIU berada pada rentang 50-67\%. Seluruh sampel operator DAMIU yang berada di Kecamatan Koto Tangah berada pada kategori cukup dan baik terhadap higiene sanitasi operator.

\section{Analisis Korelasi}

Higiene sanitasi seperti higiene pada peralatan air baku, higiene pada tempat produksi dan higiene sanitasi operator juga dapat mempengaruhi kualitas air minum. Oleh karena itu perlu diketahui korelasi antara faktor-faktor tersebut terhadap keberadaan bakteri Total Coliform .

1. Hubungan Antara Higiene Sanitasi pada Peralatan Air

Baku dengan Total Coliform pada Air Baku

Grafik hubungan kandungan Total Coliform pada air baku dengan higiene sanitasi pada peralatan air baku dapat dilihat pada Gambar 5.

Hasil regresi linier menunjukkan variabel x bernilai negatif yang artinya kandungan Total Coliform pada air baku dengan higiene sanitasi operator memiliki hubungan berbanding terbalik dimana semakin tinggi higiene sanitasi pada peralatan air baku maka kandungan Total Coliform pada air baku akan semakin rendah.

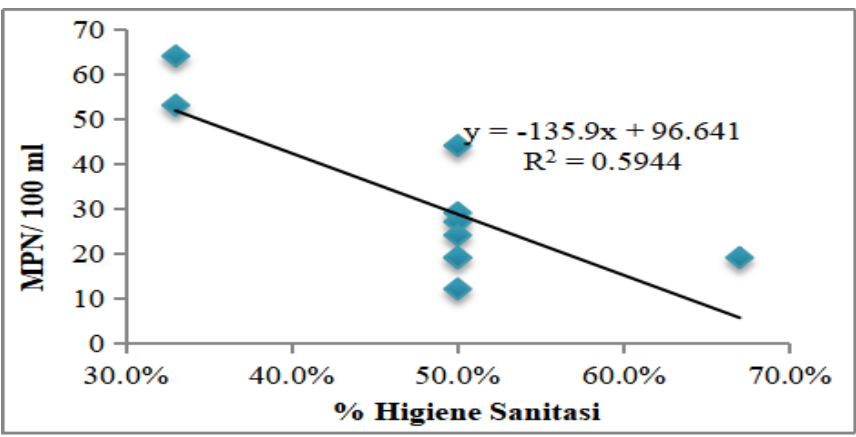

Gambar 5. Korelasi antara higiene sanitasi pada peralatan air baku dengan total coliform pada air baku 
Tabel 1. Korelasi higiene sanitasi pada peralatan air baku dengan total coliform pada air baku

\begin{tabular}{lll}
\hline Persamaan Regresi & $\mathbf{R}^{2}$ & $\mathbf{r}$ \\
\hline $\mathrm{y}=-135,9 \mathrm{x}+96,64$ & $59,4 \%$ & 0,770 \\
\hline
\end{tabular}

Higiene santasi pada peralatan air baku sangat mempengaruhi kandungan Total Coliform dibuktikan dengan nilai koefisien determinasi $\left(\mathrm{R}^{2}\right)$ yang melebihi $55 \%$ yaitu pada 59,4\%. Artinya lebih dari 59,4\% kandungan Total Coliform dipengaruhi oleh higiene sanitasi pada peralatan air baku dan untuk sisanya dipengaruhi oleh faktor lain di luar higiene sanitasi pada peralatan air baku DAMIU. Sedangkan nilai koefisien korelasi (r) melebihi 0,7 yaitu pada 0,77 yang artinya pengaruh dan kuat hubungan korelasi higiene sanitasi pada peralatan air baku dan kandungan Total Coliform pada air baku adalah sangat kuat.

2. Hubungan Antara Higiene Sanitasi pada Peralatan dan

Tempat Produksi dengan Total Coliform pada Air Hasil Produksi

Grafik hubungan kandungan Total Coliform pada air hasil produksi dengan higiene sanitasi operator dapat dilihat pada Gambar 6.

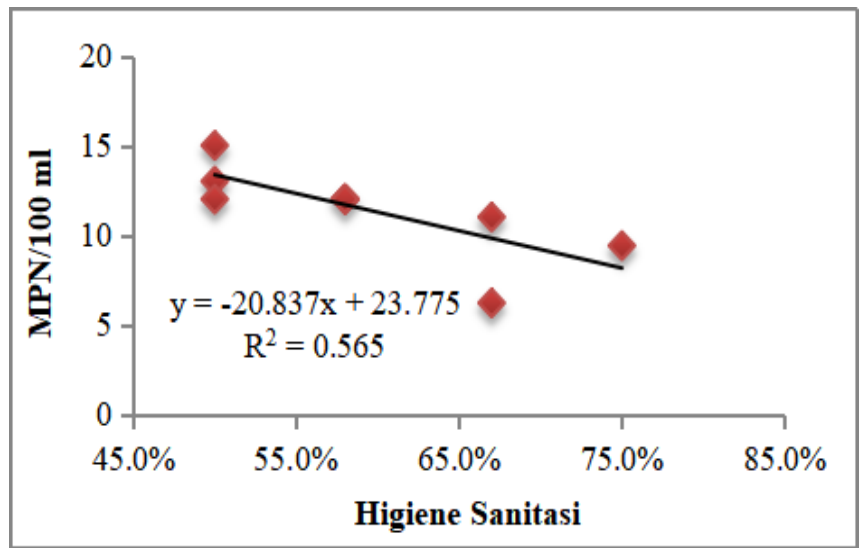

Gambar 6. Korelasi higiene sanitasi pada peralatan dan tempat produksi dengan total coliform pada air hasil produksi

Hasil berupa variabel $\mathrm{x}$ yang bernilai negatif, artinya kandungan Total Coliform pada air hasil produksi dengan higiene sanitasi pada peralatan dan tempat produksi memiliki hubungan berbanding terbalik dimana semakin tinggi higiene sanitasi pada peralatan dan tempat produksi maka kandungan Total Coliform pada air hasil produksi akan semakin rendah.

Tabel 2. Korelasi higiene sanitasi pada peralatan dan tempat produksi dengan total coliform pada air hasil produksi

\begin{tabular}{lll}
\hline Persamaan Regresi & $\mathbf{R}^{2}$ & r \\
\hline $\mathrm{y}=-20,83+23,77$ & $56,5 \%$ & 0,751 \\
\hline
\end{tabular}

Higiene santasi pada peralatan dan tempat produksi sangat mempengaruhi kandungan Total Coliform dibuktikan dengan nilai koefisien determinasi $\left(\mathrm{R}^{2}\right)$ yaitu $56,5 \%$. Artinya lebih dari 56,5\% kandungan Total Coliform dipengaruhi oleh higiene sanitasi pada peralatan dan tempat produksi dan untuk sisanya dipengaruhi oleh faktor lain di luar higiene sanitasi pada peralatan dan tempat produksi DAMIU. Sedangkan nilai koefisien korelasi (r) melebihi 0,7 yaitu pada 0,751 yang artinya pengaruh dan kuat hubungan korelasi higiene sanitasi pada peralatan dan tempat produksi dengan kandungan Total Coliform pada air hasil produksi adalah kuat.

3. Hubungan Antara Higiene Sanitasi Operator dengan Total Coliform pada Air Hasil Produksi

Grafik hubungan kandungan Total Coliform pada air hasil produksi dengan higiene sanitasi operator dapat dilihat pada Gambar 7.

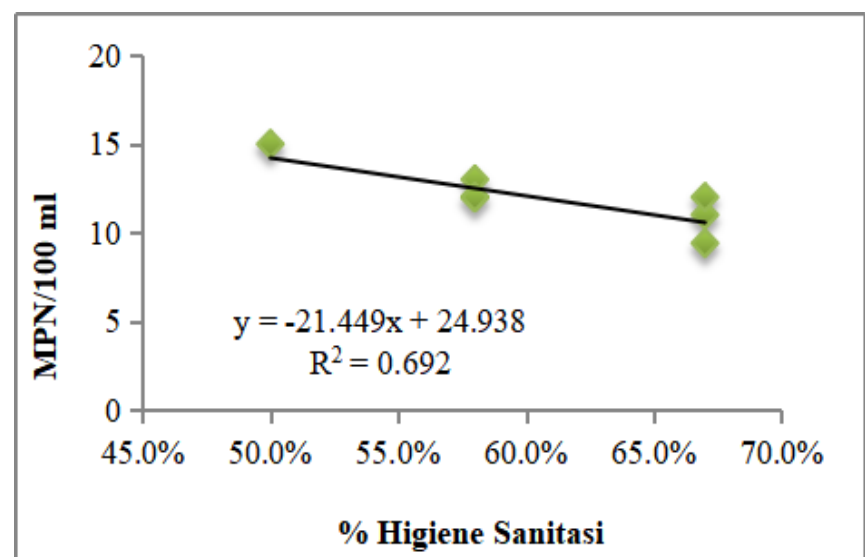

Gambar 7. Korelasi higiene sanitasi operator dengan total coliform pada air hasil produksi

Dapat dilihat pada Gambar 7, variabel x pada grafik bernilai negatif. Hal ini berarti kandungan Total Coliform pada air produksi dengan higiene sanitasi operator memiliki hubungan berbanding terbalik dimana semakin tinggi higiene sanitasi operator maka kandungan Total Coliform pada air produksi akan semakin rendah.

Tabel 3. Korelasi higiene sanitasi operator dengan total coliform pada air hasil produksi

\begin{tabular}{lll}
\hline Persamaan Regresi & $\mathbf{R}^{\mathbf{2}}$ & $\mathbf{r}$ \\
\hline $\mathrm{y}=-21,44 \mathrm{x}+24,93$ & $69,2 \%$ & 0,831 \\
\hline
\end{tabular}

Higiene santasi operator sangat mempengaruhi kandungan Total Coliform pada air produksi dibuktikan dengan nilai koefisien determinasi $\left(\mathrm{R}^{2}\right)$ yaitu $81,1 \%$. Artinya lebih dari 69,2\% kandungan Total Coliform dipengaruhi oleh higiene sanitasi operator dan untuk sisanya dipengaruhi oleh faktor lain di luar higiene sanitasi operator DAMIU. Sedangkan nilai koefisien korelasi (r) melebihi 0,8 yaitu pada 0,831 yang artinya pengaruh dan kuat hubungan korelasi higiene sanitasi operator dengan kandungan Total Coliform pada air hasil produksi adalah sangat kuat.

\section{SIMPULAN}

1. Berdasarkan hasil uji terhadap air baku dan air hasil produksi semua DAMIU mengandung bakteri Total Coliform sehingga tidak memenuhi batas baku mutu berdasarkan Peraturan Menteri Kesehatan Republik Indonesia Nomor 492/MENKES/PER/IV/2010 tentang Persyaratan Kualitas Air Minum dimana batas baku mutu untuk Escherichia coli 0 per/100 ml. Setelah dilakukan uji pelengkap (completed test), pada air baku terdapat 5 DAMIU dan pada air hasil produksi terdapat 2 DAMIU yang positif bakteri $E$. coli; 
2. Hubungan antara higiene sanitasi dengan keberadaan Total Coliform dalam AMIU adalah berbanding terbalik dengan korelasi sangat kuat dengan nilai $\mathrm{r}$ pada higeine sanitasi peralatan air baku yaitu 0,852 , kemudian 0,751 pada higiene sanitasi peralatan produksi dan 0,831 pada pada higiene operator. Aspek yang paling mempengaruhi jumlah Total Coliform dalam air adalah higiene sanitasi operator.

\section{Daftar Pustaka}

Athena. 2004. Kandungan Bakteri Total coli dan Escherichia coli/Fecal coli Air Minum Isi Ulang di Jakarta, Bekasi, dan Tangerang. Buletin Penelitian Kesehatan. 32(4).

Bambang, A. 2014. Analisis Cemaran Bakteri Coliform Dan Identifikasi Escherichia Coli Pada Air Isi Ulang Dari Depot Di Kota Manado. Jurnal Ilmiah FarmasiUNSRAT, 3(3).

Blodgett, R. 2006. Apendix 2. Most Probable Number from Serial Dilution. BAM (Bacteriological Analytical Manual), Chapter 4. FDA (Food and Drug Administration).

Dinas Kesehatan Kota Padang. 2017. Depot Air Minum Isi Ulang di Kota Padang. Padang: Dinkes Padang.

Dinas Kesehatan Kota Padang. 2016. Profil Kesehatan Kota Padang. Padang: Dinkes Padang.

Kementerian Kesehatan. 2010. Peraturan Menteri Kesehatan Republik Indonesia Nomor 492/Menkes/Per/IV/2010 tentang Persyaratan Kualitas Air Minum, Kementerian Kesehatan Republik Indonesia. Jakarta

Kementrian Perindustrian dan Perdagangan. 2004. Keputusan Menteri Perindustrian dan Perdagangan Nomor 651/MPP/Kep/10/2004 tentang Persyaratan Teknis Depot Air Minum dan Perdagangannya. Kementerian Perindustrian dan Perdagangan Republik Indonesia. Jakarta

Marpaung, M. 2013. Uji Kualitas Air Minum Isi Ulang di Kecamatan Sukolilo Surabaya ditinjau dari Perilaku dan Pemeliharaan Alat. Jurnal teknik POMITS, 2(2).

Radji, M. 2008. Pemeriksaan Bakteriologis Air Minum Isi Ulang di Beberapa Depot Air Minum Isi Ulang di Daerah Lenteng Agung dan Srengseng Sawah Jakarta Selatan. Majalah Ilmu Kefarmasian, 5(2).

Rahayu. 2013. Faktor Risiko Pencemaran Mikrobiologi pada Air Minum Isi Ulang di Kabupaten Tegal. Jurnal Kesehatan Lingkungan Indonesia, 12(2).

Rofi'I, F. 2009. Hubungan Antara Jumlah Total Bakteri dan Angka Katalase Terhadap Daya Tahan Susu. Tugas Akhir Sarjana. Fakultas Kedokteran Hewan Institut Pertanian Bogor.

Tirta, D. 2017. Pengendalian Kontaminasi Total Coliform pada DAMIU dengan Konsep HACCP. Tugas Akhir Sarjana. Jurusan Teknik Lingkungan Fakultas Teknik Universitas Andalas.

Wandrivel R. 2012. Kualitas Air Minum yang diproduksi Depot Air Minum Isi Ulang di Kecamatan Bungus Padang Berdasarkan Persyaratan Mikrobiologi. Jurnal Kesehatan Andalas, 1(3).

\author{
Nomenklatur \\ Keterangan : $\quad \mathrm{y}=$ Total Coliform (MPN/100ml) \\ $\mathrm{x}=$ Persentase Higiene Sanitasi $(\%)$
}

